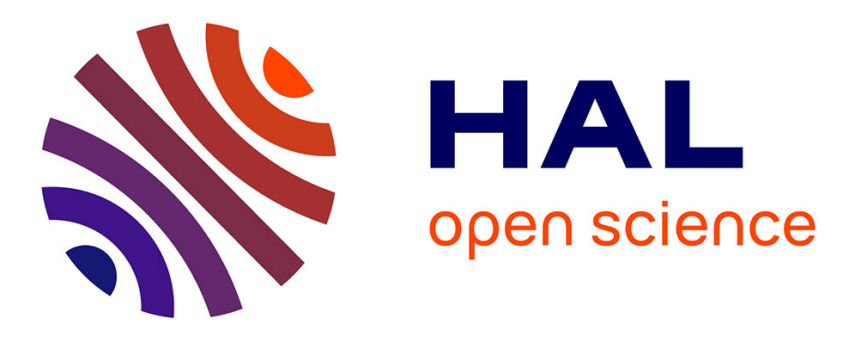

\title{
Yeast NDI1 improve oxidative phosphorylation capacity and increases protection against oxidative stress and cell death in cells carrying a Leber's hereditary optic neuropathy mutation
}

Jeong Soon Park, You-Fen Li, Yidong Bai

\section{- To cite this version:}

Jeong Soon Park, You-Fen Li, Yidong Bai. Yeast NDI1 improve oxidative phosphorylation capacity and increases protection against oxidative stress and cell death in cells carrying a Leber's hereditary optic neuropathy mutation. Biochimica et Biophysica Acta - Molecular Basis of Disease, 2007, 1772 (5), pp.533. 10.1016/j.bbadis.2007.01.009 . hal-00562761

\section{HAL Id: hal-00562761 \\ https://hal.science/hal-00562761}

Submitted on 4 Feb 2011

HAL is a multi-disciplinary open access archive for the deposit and dissemination of scientific research documents, whether they are published or not. The documents may come from teaching and research institutions in France or abroad, or from public or private research centers.
L'archive ouverte pluridisciplinaire HAL, est destinée au dépôt et à la diffusion de documents scientifiques de niveau recherche, publiés ou non, émanant des établissements d'enseignement et de recherche français ou étrangers, des laboratoires publics ou privés. 


\section{Accepted Manuscript}

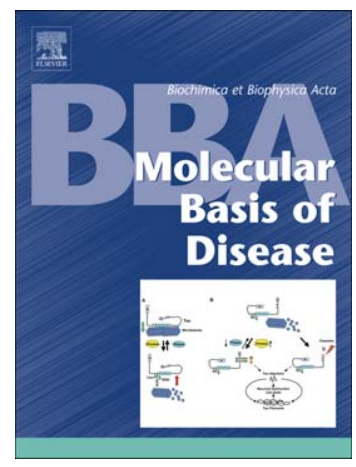

Yeast NDI1 improve oxidative phosphorylation capacity and increases protection against oxidative stress and cell death in cells carrying a Leber's hereditary optic neuropathy mutation

Jeong Soon Park, You-fen Li, Yidong Bai

PII: $\quad$ S0925-4439(07)00029-4

DOI: doi: $10.1016 / j . b b a d i s .2007 .01 .009$

Reference: $\quad$ BBADIS 62685

To appear in: $\quad$ BBA - Molecular Basis of Disease

Received date: 15 August 2006

Revised date: 21 December 2006

Accepted date: 16 January 2007

Please cite this article as: Jeong Soon Park, You-fen Li, Yidong Bai, Yeast NDI1 improve oxidative phosphorylation capacity and increases protection against oxidative stress and cell death in cells carrying a Leber's hereditary optic neuropathy mutation, BBA - Molecular Basis of Disease (2007), doi: 10.1016/j.bbadis.2007.01.009

This is a PDF file of an unedited manuscript that has been accepted for publication. As a service to our customers we are providing this early version of the manuscript. The manuscript will undergo copyediting, typesetting, and review of the resulting proof before it is published in its final form. Please note that during the production process errors may be discovered which could affect the content, and all legal disclaimers that apply to the journal pertain. 
Yeast NDI1 improve oxidative phosphorylation capacity and increases protection against oxidative stress and cell death in cells carrying a Leber's Hereditary Optic Neuropathy mutation

Department of Cellular and Structural Biology, University of Texas Health Science Center at San Antonio, San Antonio, Texas 78229

*Corresponding author.Tel: +1 210567 0561; fax: +1 210567 3803. E-mail address: baiy@uthscsa.edu (Yidong Bai)

Key Words: mitochondrial, complex I, LHON, NDI1, oxidative stress, apoptosis 


\begin{abstract}
G11778A in the subunit ND4 gene of NADH dehydrogenase complex is the most common primary mutation found in Leber's hereditary optic neuropathy (LHON) patients. The NDI1 gene, which encodes the internal NADH -quinone oxidoreductase in Saccharomyces cerevisiae, was introduced into the nuclear genome of a mitochondrial defective human cell line, Le1.3.1, carrying the G11778A mutation. In transformant cell lines, LeNDI1-1 and -2, total and complex I-dependent respiration were fully restored and largely resistant to complex I inhibitor, rotenone, indicating a dominant role of NDI1 in the transfer of electrons in the host cells. Whereas the original mutant Le1.3.1 cell grows poorly in medium containing galactose, the transformants have a fully restored growth capacity in galactose medium, although the ATP production was not totally recovered. Furthermore, the increased oxidative stress in the cells carrying the G11778A mutation was alleviated in transformants, demonstrated by a decreased reactive oxygen species (ROS) level. Finally, transformants were also shown to be desensitized to induction to apoptosis and also exhibit greater resistance to paraquat-induced cell death. It is concluded that the yeast ND11 enzyme can improve the oxidative phosphorylation capacity in cells carrying the G11778A mutation and protect the cells from oxidative stress and cell death.
\end{abstract}




\section{Introduction}

The mitochondrial respiratory NADH-ubiquinone oxidoreductase (complex I) is the major entry point for electrons into the electron transport chain. It is embedded in the inner membrane of mitochondria and is capable of dehydrogenating NADH and shuttling electrons to ubiquinone in a rotenone-sensitive pathway [1]. The mammalian complex I consists of 46 subunits [2, 3], and seven of them are encoded by mitochondrial genes [4, 5]. Complex I deficiency has been associated with various human diseases including some neurodegenerative disorders [6]. In particular, mutations in mitochondrial DNA (mtDNA)-encoded genes have been identified as the primary genetic cause for Leber's hereditary optical neuropathy (LHON) [7].

LHON, characterized by acute or subacute bilateral visual loss [8], was one of first human diseases linked to mtDNA mutations. First described last century [9], LHON was found to be inherited only through maternal transmission $[10,11]$. However, it was not until 1988 that Wallace and colleagues identified a point mutation at mitochondrial genome position 11778 in complex I subunit ND4 gene from 11 families with LHON from Finland and the USA [12]. Subsequent studies have identified two more primary mutations at position 3460 in ND1 and position 14484 in ND6 genes [13-15]. These three mutations account for more than $90 \%$ of all LHON cases $[16,17]$.

The G11778A mutation is responsible for more than half of LHON cases reported so far in various areas in the world $[8,18]$. This $\mathrm{G}$ to A transition changes conserved arginine to histidine in the ND4 subunit. Analysis in the muscle biopsy and immortalized lymphoblasts derived from LHON patients carrying the G11778A mutation revealed a reduction in the complex I specific activity [19]. Hofhaus et al further reported that the defect in complex I function was transferred along with the mtDNA as the human cell line transformed with mitochondria from the LHON patients carrying the G11778A mutation exhibited a significant decrease in complex I-dependent respiration and growth capacity in galactose medium [20]. 
In contrast to mammalian cells, Saccharomyces cerevisiae lack complex I. Instead they have a nucleus-encoding NDI1 gene [21-23]. Like complex I, the yeast NDI1 enzyme is the main entry point into the respiratory chain [23]. NDI1 has been shown to be active in bacteria [24], Chinese hamster [25] and human cells $[26,27]$. The yeast enzyme was also found coupled to the downstream portion of host respiratory chain. It was further shown to restore the oxidative phosphorylation capacity in a human cell deficient in the assembly of complex I [27].

Because most of the pathogenic mtDNA mutations associated with inherited mitochondrial diseases are mild missense mutations, it is important to investigate the behavior of the yeast NDI1 enzyme in human cells carrying a pathogenic mutation where the complex I is still intact and partially active. Although complex I-type enzymes and NDI1-type enzymes coexist in the mitochondria of some bacteria, plants, and fungus $[25,27]$, it is significant to study the potential interaction between these two enzymes in the human background if NDI1 is to be considered a potential gene therapeutic tool. In the present study, the NDI1 gene was introduced into Le1.3.1 cell, a human cell line carrying the G11778A mutation derived from a LHON patient. We found that NDI1 protein improved the oxidative phosphorylation capacity of the host cells and at the same time, protected the cells against the oxidative stress and cell death.

\section{Materials and methods}

\subsection{Cell lines and media.}

143B (ATCC CRL 8303) is a human osteosarcoma-derived cell line. Le1.3.1 was obtained by transferring mitochondria from cultures of skin fibroblast established from a LHON patient into a mtDNA-less line $\rho^{\circ} 206$ derived from 143B cell [20]. All the cell lines used in the present work were grown as monolayer in Dulbecco's modified Eagle's medium (DMEM) supplemented with 10\% fetal bovine serum (FBS). 


\subsection{NDI1 transfection.}

The construction of the NDI1-expression vector pHook(NDI1) was described previously [25].

Le1.3.1 cells were transfected with pHook(NDI1) by the calcium-phosphate precipitation method [28] and lipofactamine 2000 kit (Invitrogen). The transfectant cell lines, including LeNDI1-1 (by calciumphosphate precipitation) and -2 (by lipofactamine), were isolated by selection in the DMEM with 10\% FBS and $0.4 \mathrm{mg} / \mathrm{ml}$ active G418 (geneticin) for 2 weeks, and then were maintained at $0.1 \mathrm{mg} / \mathrm{ml} \mathrm{G} 418$. As the transfection control lines, LeVec-1 and -2 cells were generated by introducing pHook 1into Le1.3.1. cells with lipofactamine. All the transfectants were derived from single cells.

\subsection{NDI1 gene and mRNA detection by PCR amplification.}

The presence of the NDI1 gene in the transfectant cell lines was analyzed by polyacrylamide gel electrophoresis after PCR amplification of total cell DNA [27]. The PCR reactions were carried out by using primers NDI1-For, AGCACAGCGACAAACCAAAC, and NDI1-Rev, TCAGGTTGGTATAGCTGGCT, to amplify the NDI1 gene. Another set of primers was used for PCR amplification of the mitochondrial ND4 gene as a control: ND4-For, TGCCCAAGAACTATCAAACTCC, and ND4-Rev, GGTTTTGGATGAGAATGGCTG. PCR was first carried out at $94^{\circ} \mathrm{C}$ for $1 \mathrm{~min}, 50^{\circ} \mathrm{C}$ for $1 \mathrm{~min}$, and $72^{\circ} \mathrm{C}$ for $1 \mathrm{~min}$. The first 5 cycles were with NDI1 primer set only, and then ND4 primer set was added for another 30 cycles. Total RNA was isolated by RNAzol B procedure (Tel-Test, Inc., Friendswood, TX). RNA extracted from $5 \times 10^{6}$ cells was treated with 10 units of RNase-free RQ DNase (Promega) at $37^{\circ} \mathrm{C}$ for 30min. After phenol/chloroform/isoamyl alcohol extraction and ethanol precipitation, the reverse transcription reactions were carried out as previously described [29]. PCR amplification was performed using the same conditions as for DNA analysis, and the PCR products were analyzed by polyacrylamide gel electrophoresis. 


\subsection{LHON mutation detection}

The G11778A point mutation was detected by digestion with a restriction endonuclease, MaeIII (Roche Molecular Biochemicals, Germany) because the G to A transition at position 11778 creates a Mae III site. Genomic DNA extracted from 143B, Le1.3.1 and LeNDI1-1 and -2 cells were subjected to PCR amplification of a portion of ND4 gene using the ND4-4For, TGCCCAAGAACTATCAAACT, and ND4-6Rev, TAAGGGGTCGTAAGCCTCTG, as primers. PCR was carried out at $94^{\circ} \mathrm{C}$ for $30 \mathrm{sec}, 58^{\circ} \mathrm{C}$ for $45 \mathrm{sec}$, and $72^{\circ} \mathrm{C}$ for $1 \mathrm{~min}$ for 35 cycles. The PCR product was purified with the QIAEX II gel extraction kit (QIAGEN, CA). The extracted DNA was then digested by MaeIII at $55^{\circ} \mathrm{C}$ for $4 \mathrm{hrs}$. The presence or absence of the G11778A mutation was revealed by analysis of the electrophoretic patterns in an $8 \%$ acrylamide gel.

\section{5. $\mathrm{O}_{2}$ consumption measurement}

As described previously [30], determination of the $\mathrm{O}_{2}$ consumption rate in intact cells was carried out with $5 \times 10^{6}$ cells in Tris-based, $\mathrm{Mg}^{2+}, \mathrm{Ca}^{2+}$-deficient (TD) buffer. FCCP (carbonylcyanide p-(trifluoromethoxy) phenylhydrazone), $1 \mu \mathrm{M}$, was added to uncouple mitochondrial respiration. For measurements of $\mathrm{O}_{2}$ consumption rate in digitonin-permeabilized cells, about $5 \times 10^{6}$ cells were resuspended in respiration buffer (20mM HEPES, pH7.1, 250mM sucrose, $2 \mathrm{mM} \mathrm{Kp}_{\mathrm{i}}, 10 \mathrm{mM} \mathrm{MgCl}$, and 1.0mM ADP). The measurements were carried out in two chambers of an YSI Model 5300 Biological Oxygen monitor. The substrate concentrations were as follows: malate, glutamate, succinate, and glycerol-3-phosphate (G-3-P), 5mM; ascorbate, 10mM; $N, N, N^{\prime}, N^{\prime}$-tetramethyl-p-phenylenediamine (TMPD), 0.2mM; rotenone, 100nM; flavone, 0.5mM; antimycin A, 20nM.

\subsection{Mitochondrial respiratory complexes enzymatic activities}


Submitochondrial fractions were obtained by freeze-thawing of isolated mitochondria in hypotonic buffer ( $25 \mathrm{mM}$ potassium phosphate, $\mathrm{pH} 7.2$ and $5 \mathrm{mM} \mathrm{MgCl}_{2}$ ) [31]. The methods to measure the complexes activities were based on those described by Birch-Machin and Turnbull [32]. In particular, the activity of NADH:ubiquinone oxidoreductase (Complex I) was assayed with $0.13 \mathrm{mM} \mathrm{NADH}$ and $65 \mu \mathrm{M}$ decylubiquinone following the decrease in absorbance due to the oxidation of NADH at $340 \mathrm{~nm}\left(\varepsilon=6.22 \times 10^{3} \mathrm{M}^{-1} \mathrm{~cm}^{-1}\right)$, in presence of $2 \mathrm{mM} \mathrm{KCN}$ and $2 \mu \mathrm{g} / \mathrm{ml}$ Antimycin A to block complex IV and III activities, respectively. Enzyme activities were normalized to the protein amount. For Complex III and IV activity assay, submitochondrial fractions were solubilized with dodecyl maltoside. Complex III activity was measured by reduction of cytochrome $\mathrm{C}(\mathrm{III})$ at $550 \mathrm{~nm}\left(\varepsilon=21 \mathrm{mM}^{-1} \mathrm{~cm}^{-1}\right)$ by using D-ubiquinol-2 as an electron donor at $25{ }^{\circ} \mathrm{C}$. Complex IV activity was measured by oxidation of cytochrome C(II) at $550 \mathrm{~nm}$ $\left(25^{\circ} \mathrm{C}\right)$. All measurements were performed in triplicate. The protein extracts were quantified with Bradford method (Bio-rad, Hercules, CA).

\subsection{Blue Native Gel electrophoresis}

Mitochondria were isolated as previously described [30]. Blue-Native PAGE (BN-PAGE) [33, 34] was used for separation of respiratory complexes on $4-13 \%$ polyacrylamide gradient gels. $50 \mu \mathrm{g}$ of mitochondrial proteins were loaded on a minigel of $1.5 \times 70 \times 82 \mathrm{~mm}$ (Bio-Rad). The protein complexes were detected by western blot and immunodetection with antibodies MS111, MS204, MS304, MS404, and MS507 for complex I, II, III, IV, and V respectively. All the antibodies are from Mitosciences Inc.

\subsection{ATP production}

ATP measurements were carried out based on the procedure previously described by Manfredi et al.[35]. For luciferase assays, aliquots of $1 \times 10^{6}$ cells were incubated in DMEM containing the following 
combinations of substrates and inhibitors: glucose $(4.5 \mathrm{mg} / \mathrm{ml})$ plus $110 \mathrm{mg} / \mathrm{L}$ pyruvate; glucose plus 15 $\mu \mathrm{g} / \mathrm{ml}$ the ATP synthase inhibitor oligomycin. Cells were placed in noncoated 24-well plastic plates and incubated with gentle rocking (to prevent cell attachment) for an hour at $37^{\circ} \mathrm{C}$. Cells were then collected by centrifugation, and resuspended in $100 \mu$ l buffer containing $25 \mathrm{mM}$ Tris, $\mathrm{pH} 7.4$ and $150 \mathrm{mM}$ EDTA. The above solution was boiled at $100^{\circ} \mathrm{C}$ for 5 mins and centrifuged. The Luciferrin-luciferase mixture (Invitrogen) was added to the cell suspension (final concentration, $2 \mathrm{mM}$ ), and light emission was measured in a Synergy ${ }^{\text {TM }}$ HT Multi-Detection Microplate Reader (Bio-Tek Instruments Inc., Winooski, VT). A standard ATP/luminescence curve was constructed by measuring luminescence derived from ATP solutions containing $0,0.001,0.01,0.1,1$, and $10 \mu \mathrm{M}$ ATP in double distilled water and luciferrinluciferase mixture.

\subsection{Growth measurement}

Multiple identical samples of $5 \times 10^{3}$ cells were plated on 6-well plates in $5 \mathrm{ml}$ of medium and cells were cultured at $37^{\circ} \mathrm{C}$ for 24 hours. The medium was changed the next day with appropriate media (Glucose, DMEM which contain $4.5 \mathrm{mg}$ glucose/ml and $0.11 \mathrm{mg}$ of pyruvate/L or Galactose, DMEM lacking glucose and containing $0.9 \mathrm{mg}$ of galactose $/ \mathrm{ml}$ and $0.5 \mathrm{mg}$ of pyruvate/L, both supplemented with $10 \%$ dialyzed FBS). Trypan blue exclusion method was then used to count cell numbers. Cells were counted on a daily basis for 7 days.

\subsection{ROS analysis}

ROS generation was detected by both 6-carboxy-2',7'-dichlorofluorescin diacetate (carboxy$\mathrm{H}_{2}$ DCFDA) and Mitosox Red reagent (both from Invitrogen). For carboxy- $\mathrm{H}_{2}$ DCFDA assay, cells were harvested and counted by trypan blue exclusion, and then about $1 \times 10^{4}$ cells were resuspended with HBSS buffer and incubated with $1 \mu \mathrm{M}$ carboxy- $\mathrm{H}_{2}$ DCFDA in the loading medium $(125 \mathrm{mM} \mathrm{KCl}, 10 \mathrm{mM}$ HEPES, $5 \mathrm{mM} \mathrm{MgCl}_{2}$, and $2 \mathrm{mM} \mathrm{K}_{2} \mathrm{HPO}_{4}, \mathrm{pH} 7.4$ ) in $5 \% \mathrm{CO}_{2}$ at $37^{\circ} \mathrm{C}$ for 30 mins. After carboxy- 
$\mathrm{H}_{2}$ DCFDA was removed, the cells were washed and incubated with HBSS buffer and the fluorescence was measured and recorded. Carboxy- $\mathrm{H}_{2}$ DCFDA -loaded cells were placed in a Perkin Elmer 1000 multiwell fluorescence plate with temperature maintained at $37^{\circ} \mathrm{C}$. The excitation filter was set at $485 \pm$ $10 \mathrm{~nm}$ and the emission filter was set at $530 \pm 12.5 \mathrm{~nm}$. The fluorescence from each well was captured, digitized, and stored on a computer using Cytofluor (Version 2.0, Perkin Elmer). Data points were taken every $1 \mathrm{~min}$ for $60 \mathrm{~min}$ and the data were exported to Excel spreadsheet software for analysis.

Superoxide measurements were carried out with Mitosox assay [36]. About 5 x $10^{5}$ cells were resuspended with HBSS buffer and then incubated with 100nM Mitosox (Ex 492nm and Em 595nm) in loading medium with $5 \% \mathrm{CO}_{2}$ at $37^{\circ} \mathrm{C}$ for 10 mins. Cells were then washed, and the fluorescence was measured and recorded in a Perkin Elmer 1000 multiwell fluorescence plate with temperature maintained at $37^{\circ} \mathrm{C}$.

\subsection{Apoptosis assay}

To evaluate apoptosis, cells were first_grown on the cover glass in 6 well plates and treated with $500 \mathrm{nM}$ staurosporine for 6 hours or $250 \mu \mathrm{M}$ paraquat for 48 hours. Cells were then washed three times with PBS and fixed with 70\% Ethanol. Fixed cells were washed again with PBS and stained with 4,6diamidino-2-phenylindole (DAPI, $1 \mu \mathrm{g} / \mathrm{ml}$, Sigma) for $30 \mathrm{mins}$. The number of DAPI stained cells was determined by fluorescence microscopy (Zeiss-Axioplan, Oberkochen, Germany) using a UV filter $(365 / 420 \mathrm{~nm})$. Apoptotic cells were morphologically defined by cytoplasmic and nuclear shrinkage, and chromatin condensation or fragmentation. All of experiments were carried out on cells with less than $80 \%$ of confluence. To quantify the percentage of apoptotic cells, 4 - 5 different fields were viewed and at least 1000 cells were observed.

TUNEL assay was performed by fallowing Promega protocol. Cells were first fixed with $4 \%$ paraformaldehyde and permeabilized with $0.2 \%$ Triton X-100, and then reacted with rTdT(terminal deoxyribonucleotidyl Transferase) enzyme for 60 minutes at 37 . After incubation with Streptoavidin HRP for 30 minutes, labeled nick ends of DNA strands were visualized with DAB method. To quantify 
the percentage of apoptotic cells, 3 different fields were viewed and over 100 cells each time were observed.

Caspase-Glo 3/7 activity assay: 2 × $10^{4}$ cells were grown in 96well plates and subsequently treated with $500 \mathrm{nM}$ staurosporine and $250 \mu \mathrm{M}$ paraquat respectively. After the treatment, Caspase-Glo 3/7 reagent (Promega) was added and then incubated for $1 \mathrm{hr}$. The luminescence (relative light unit, RLU) measured by a Synergy ${ }^{\mathrm{TM}}$ HT Multi-Detection Microplate Reader (Bio-Tek Instruments Inc., Winooski, VT).

\subsection{Statistical analysis}

$P$, probability, values were calculated by using the ANOVA test contained in the Minitab program.

\section{Results}

\subsection{Transfection of human cells carrying a G11778A mutation with yeast NDI1 gene}

Le1.3.1 is a human cell line carrying the homoplasmic G11778A mutation in 143B nuclear background [20]. To introduce NDI1 gene to cells with LHON mutation, Le1.3.1 cells were transfected with the plasmid pHook (NDI1). 48 transfectants were isolated by resistance to $0.4 \mathrm{mg} / \mathrm{ml} \mathrm{G} 418$, and 16 were picked to check if the transfection was successful. Among 16 clones, 10 were confirmed to carry the NDI1 gene, LeNDI1-1 and -2 were selected for further analysis. Two transfection control lines, LepVec-1 and -2, were generated by introducing pHook vector without NDI1 gene into Le1.3.1 cells. The success of the transfection was verified by PCR amplification. As shown in Fig.1A, a NDI1 gene fragment was detected in LeNDI1-1 and -2 cells. The successful expression of NDI1 gene was confirmed by detection of NDI1 mRNA by reverse transcription-PCR (RT-PCR) (Fig. 1B). The results also showed that LeNDI1-1 had a higher NDI1 gene copy and exhibited a higher NDI1 mRNA level. The 
reason why DNA and RNA levels are not proportional is probably because that not all the trans-genes are transcribed, and that are more likely to happen with transfectant high copy number transgene (LeNDI1-1).

To confirm that Le1.3.1 and its NDI1 transformants, LeNDI1-1 and -2 cells, do carry the G11778A mutation, a portion of ND4 gene was PCR-amplified then digested with a restriction enzyme MaeIII which recognizes GTNAC. The G to A transition at 11778 changes the original GTCGC to GTCAC and creates a new Mae III site. As shown in Fig 2, the 896bp portion of ND4 gene in control 143B cells contains 3 MaeIII sites thus yielded 4 bands with the sizes of 346, 255, 238 and 57 bp (not shown in the picture) after digestion. While in Le1.3.1 and both NDI1 transfectant cells, the 255bp fragment was further cut into two smaller bands at 131 and $124 \mathrm{bp}$. These results indicated that both the NDI1 transfectants still carried the homoplasmic mutation at 11778 site.

\subsection{Respiration properties in the NDI1 transformants}

To evaluate the activity of the yeast NDI1 gene in human cells carrying the mtDNA G11778A mutation, the respiration properties of the control 143B, the mutant Le1.3.1, and the NDI1 transformants, LeNDI1-1 and -2 cell lines were investigated in detail. First, we measured the endogenous respiration activities of intact 143B, Le1.3.1, LeNDI1-1 and -2 cells. As shown in Fig 3A, total respiration in NDI1 transformants was fully restored. The respiration rates in LeNDI1-1 and -2 cells increased by 34.4 $(p<0.01)$ and $46.6 \%(p<0.05)$ compared with the parental Le1.3.1 cells. In the presence of the chemical uncoupler FCCP that can completely uncouple mitochondria and raise the respiratory capacity to a maximal level, oxygen consumption in LeNDI1-1 and -2 cells were also totally restored (Fig. 3A).

To further exanimate the respiration activities of each complex in the NDI1 transformed cell, the substrate-dependent respiration was analyzed on digitonin-permeabilized cells. The malate/glutamatedriven respiration which reflects the rate-limiting activity of complex I, the succinate/glycerol-3phosphate-driven respiration which reflects the rate-limiting activity of complex III (ubiquinonecytochrome c oxidoreductase) and ascorbate/TMPD-dependent respiration which reflects the activity of 
complex IV (cytochrome c oxidase), were measured. As shown in Fig.3B, the most significant feature in LeNDI1-1 and -2 cell lines was that the complex I-dependent respiration were $48 \%(\mathrm{p}<0.01)$ and $39.2 \%$ $(\mathrm{p}<0.005)$ higher, respectively, than the level of the mutant Le1.3.1 cells.

To distinguish the NADH dehydrogenase activity of the human complex I and of the yeast NDI1 enzyme, the difference in sensitivity to the respiratory inhibitor rotenone [23] was utilized. As shown in Fig 3C, respiration in 143B and Le1.3.1 cells were extensively inhibited by $100 \mathrm{nM}$ of complex I inhibitor, rotenone, while the respiration in LeNDI1-1 and -2 cells was largely resistant to rotenone but mostly inhibited by $0.5 \mathrm{mM}$ flavone, an NDI1 and complex I inhibitor. This result suggested that NDI1 was predominantly utilized while coexisting with a defective complex I. On the other hand, as in 143B and the parental Le1.3.1 cells, the respiration of LeNDI1-1 and -2 cells was totally sensitive to complex III inhibitor, antimycin A, indicating NDI1 has integrated into the downstream portion of human respiratory chain (Fig.3 C).

\subsection{Mitochondrial Respiratory Chain Enzyme Activities}

To complement the respiratory measurement, biochemical assays on the activities of complex I, III and IV were also carried out. Mitochondrial membranes were partially purified from isolated mitochondria[37]. Complex I (NADH-ubiquinone oxidoreductase) activity was determined by following the oxidation of $\mathrm{NADH}$ using as electron acceptor $\mathrm{DB}$, which is a soluble analogue of the endogenous acceptor, ubiquinone [32]. Complex III (ubiquinone-cytochrome c oxidoreductase) activity was measured by following the reduction of cytochrome c (III) using D-ubiquinol-2 as the electron donor. Complex IV (cytochrome c oxidase) specific activity was measured by monitoring the oxidation of cytochrome c (II). The enzymatic activities of 2 transfection control lines, LeVec-1 and -2 were also measured. As shown in Table 1, while complex I activity of Le 1.3 .1 cells was significantly lower $(74 \%, \mathrm{p}<0.005)$ than the control, it was shown to increase by $77 \%(\mathrm{p}<0.01)$ in NDI1 transfected cells compared with the parental 
Le1.3.1 cells. On the other hand, we also observed a decrease in complex III activity $(16 \%, \mathrm{p}<0.05)$ in NDI1 transformants, and no significant changes were observed in complex IV activity.

\subsection{Complex I assembly analysis}

The significant resistance of respiration to rotenone in LeNDI1-1 and -2 cells suggested that complex I was bypassed largely in electron transfer when it coexisted with NDI1 enzyme. To determine if complex I is still intact in the NDI1 transformed cells, blue native gel electrophoresis (BN-PAGE), a useful method for isolating intact membrane-bound protein complexes and for investigating the integrity of mitochondrial respiratory complexes[38], was carried out. Mitochondrial samples electrophoresed by using the BN-PAGE system were subjected to immunoblot analysis for all oxidative phosphorylative complexes. Interestingly, as shown in Fig.4, there was an increase in amount of complex I in NDI1 transformants by $14-29 \%$, indicating complex I was still stable.

\subsection{ATP synthesis}

One major difference between complex I and NDI1 is that NDI1 lacks the proton pumping ability. It is thus interesting to check the ATP production in NDI1 transformants. Total ATP level was measured by luminometry in boiled cells. Compared with Le1.3.1 cells, we found that the ATP contents increased by $72(p<0.00005)$ and $104(p<0.001) \%$ in LeNDI1-1 and -2 cells (Fig.5). We further investigated the mitochondrial oxidative phosphorylation contribution to ATP production with the addition of $15 \mu \mathrm{g} / \mathrm{ml}$ of oligomycin, an ATP synthase or complex V inhibitor. As shown in Fig.5, the oligomycin-sensitive ATP level in LeNDI1-1 and -2 cells increased by 121 and 140\%, indicating the recovery was mitochondrial.

\subsection{Growth capacity in galactose medium}


Mitochondrial oxidative phosphorylation is the major source for ATP production, while glycolysis is an alternative pathway to generate ATP. In mammalian cells, galactose cannot be utilized efficiently in the glycolytic pathway. Consequently, in medium containing galactose instead of glucose, the cells are forced to depend predominantly on mitochondrial oxidative phosphorylation as the source of energy supplies. As shown in Fig 6, all cells grew well in the regular glucose medium. However, in the galactose medium, the wildtype 143B cells still grew well, with the doubling time at 19.8 hours; the mutant Le1.3.1 cells grew rather poorly with the doubling time at 27.7 hours; the growth capacity in galactose medium was again totally recovered in LeNDI1-1 and -2 cells with the doubling time at 19.1 and 19 hours.

\section{7. $R O S$ generation and oxidative stress in the NDI1 transformants}

Oxidative stress has been suggested as a pathogenic mechanism for mitochondrial disease since mitochondria are the major source for $\operatorname{ROS}[39,40]$. We first analyzed the cellular ROS level detected by carboxy- $\mathrm{H}_{2}$ DCFDA [41]. Significant increase of ROS production $(57 \%, \mathrm{p}<0.005)$ was observed in Le1.3.1 cell compared with 143B cells (Fig. 7A). More importantly, in LeNDI1-1 and -2 cells where NDI1 was introduced into the Le1.3.1 background, ROS level was considerably decreased (about 30\%, $\mathrm{p}<0.01)$

To verify this result, we used a mitochondria-specific dye Mitosox which recognized mitochondrial superoxide radicals. Again, a substantial decrease was recorded in LeNDI1-1 and -2 cells (about 40\%, p<0.001) (Fig. 7B).

\subsection{Sensitivity to cell death}


It has been suggested that retinal ganglion cells are lost by an apoptotic pathway in LHON patients [42]. We investigated the apoptotic features in our cells. We first analyzed the apoptotic features by DAPI assay. The apoptotic nuclei were identified by the condensed chromatin gathering at the periphery of the nuclear membrane or a total fragmented morphology of nuclear bodies under the microscope. Cells were incubated with 500nM staurosporine, a protein kinase inhibitor which is often used as an inducer of apoptosis, for 6 hours, and then stained with DAPI which formed fluorescent complexes with double-stranded DNA. As shown in Fig.8A, more Le1.3.1 cells which carried G11778A mutation were apoptotic $(24 \%, \mathrm{p}<0.005)$ compared with the control $143 \mathrm{~B}$ cells $(5 \%)$, while less LeNDI11 and -2 cells exhibited such feature $(8$ and $9 \%$, respectively, $\mathrm{p}<0.005)$ compared with their parental cells.

To further investigate the apoptosis associated with oxidative stress, we examined the apoptotic features in various cells with a superoxide-generating drug, paraquat [43]. Cells were treated with $250 \mu \mathrm{M}$ paraquat for 48 hours, and apoptosis analysis was carried out. As shown in Fig 8B, the Le1.3.1 cells displayed more significant cell death $(33 \%$ apoptosis, $p<0.00001)$ compared with the control 143 B cells ( $8 \%$ apoptosis). Interestingly, LeNDI1-1 and -2 cells exhibited much more resistance to paraquatdependent cell death ( 7 and 3\%, respective, $\mathrm{p}<0.00001)$ compared with their parental cells. These results suggested complex I is an important target for oxidative stress.

Since not all cells with shrunken nuclei are undergoing apoptosis, we also carried out the TUNEL (Terminal transferase dUTP nick end labeling) assay, a common method for detecting DNA fragmentation that results from apoptotic signaling cascades. When treated with 500nM staurosporine, more Le1.3.1 cells which carried G11778A mutation were TUNEL positive $(27 \%, \mathrm{p}<0.05)$ compared with the control 143B cells (5\%), while less LeNDI1-1 and -2 cells exhibited such feature (about 5\%, $\mathrm{p}<0.005$ ) compared with their parental cells (Fig. 8C). When oxidative stress was induced by $250 \mu \mathrm{M}$ paraquat, more Le1.3.1 cells were TUNEL positive $(30 \%, \mathrm{p}<0.01)$ compared with the control $143 \mathrm{~B}$ cells (12\%). Again, LeNDI1-1 and -2 cells showed much more resistance to paraquat-dependent cell death (6 and $2 \%$, respective, $\mathrm{p}<0.05$ ) compared with their parental cells (Fig.8D). 
The apoptotic properties were further verified by Caspase-Glo 3/7 Assay which measured the caspase- 3 and -7 activities. The assay provides a luminogenic caspase- $3 / 7$ substrate, which contains the tetrapeptide sequence DEVD. Le1.3.1 cells treated with 500nM staurosporine exhibited $24 \%(\mathrm{p}<0.05)$ increase in caspase 3/7 activity while the NDI1 expression decrease the activity in cells carrying G11778A by $24-25 \%(\mathrm{p}<0.05)$ (Fig. $8 \mathrm{E})$. When oxidative stress was induced by $250 \mu \mathrm{M}$ paraquat, caspase activity was increased by 3.5 fold $(\mathrm{p}<0.05)$ in Le1.3.1 cells, and the NDI1 reduced the activities by 62$81 \%(\mathrm{p}<0.01)$ in the transfectants (Fig. 8F).

All these results supported the notion that oxidative stress mediated apoptosis might play a role in the pathogenesis of LHON cells, and bypassing complex I will make the cells more resistant to oxidative stress and cell death.

\section{Discussion}

In a previous paper, we reported that yeast NDI1 protein was localized in the inner mitochondrial membrane and integrated into the host respiratory chain after being introduced into a human cell line lacking the functional complex I assembly [27]. In the present study, we extended the exploration of the potential usefulness of the NDI1 gene as a therapeutic tool for diseases involving complex I defect by delivering the yeast NDI1 gene into a human cell line carrying an mtDNA mutation which causes LHON.

There is a controversy on the complex I function associated with G11778A mutation [44-47], probably due to the difference in the origins of the mtDNA, the recipient rho zero cells, the way to generate the cybrids and analytical methods. A partially active complex I and a compromised oxidative phosphorylation capability were recorded with the cybrids carrying the G11778A mutation in this study, as reported by the group where the mutation cells were obtained [20]. Interestingly, in the NDI1 transformants carrying the G11778A mutation, both total and the complex I-dependent respirations are largely resistant to complex I inhibitor, rotenone. The complex I content, as shown by BNG analysis, was even higher in NDI1 transfected cells. This result, to some extent, was probably due to the fact that 
NDI1-type enzyme and complex I are known to coexist in plant and fungal mitochondria and in bacteria [48]. Interestingly, a previous study reported that the respiration is totally resistant to rotenone while NDI1 gene was transfected in human embryonic kidney 293 (HEK 293) cells [26]. The discrepancy might be due the difference in copy numbers of the transgene. Nevertheless, all these results indicate that NDI1 serves as a better shuttle for electrons between NADH and ubiquinone.

One of the surprising results of this study is that the complex III activities were also shown to be reduced by enzymatic assays. These effects could be mediated by the interaction between NDI1 and other respiratory complexes. Accumulating evidence has pointed to existing of direct interaction among respiratory complexes and supercomplexes [49-51]. Further studies are required to understand the underling mechanisms.

Despite the fact that respiration fully recovered to the level of control 143 B cells in NDI1 transformants, ATP production in those cells, though increased substantially compared with their parental Le1.3.1 cells, did not reached the level of 143B. This could be due to the lack of the proton pumping translocating site in NDI1 protein [21]. Nevertheless, both LeNDI1-1 and -2 cells grew well in galactose medium where ATP generation predominantly relies on mitochondria.

The important finding from this study is NDI1 helps the cells carrying the G11778A mutation to reduce the oxidative stress and to increase resistance to apoptosis, particularly the apoptosis induced by oxidative stress. As suggested previously $[52,53]$, since complex I is one of the major site for ROS generation, bypassing the defective complex I by NDI1 would decrease the oxidative stress. However, it was reported from a previous study on ROS level in cell carrying G11778A mutation that a significant increase in ROS was recorded only in the differentiated neurons, but not in other cell types [54]. This discrepancy could be attributed to the difference in the nuclear background of the cybrids, and the variations could be introduced in the process of creation of the mtDNA-less ${ }^{\circ} \rho$ cells and the selection of trans-mitochondrial cells. Our results further demonstrated that by bypassing the electron transferring through defective complex I, not only the production of ROS, but the sensitivity to oxidative stress 
induced cell death has been decreased. Complex I, thus, appears to be both the major production and targeting site for ROS.

In a mouse model where ROS was increased as the result of inhibition of an antioxidant enzyme, mitochondrial manganese superoxide dismutase (MnSOD), a striking of the similarity of optic neuropathy to the histopathology of LHON was observed [55]. Over-production of ROS has been documented in cybrids carrying all 3 LHON mutations [56]. Meanwhile, one of the important molecular biology features of LHON is the preferential cell death of the retinal ganglion cells and atrophy of the optic nerve $[17,42]$. Cells carrying any one of the three primary mutations (G11778A, G3460A and T14484C) have been shown to undergo a caspase independent apoptosis in galactose medium [57,58], and cells carrying G11778A and G3460A mutations have also been reported to be sensitized to Fas-induced apoptosis with an increased caspase 3 activity [59]. Here we showed that with the decreasing ROS production in the NDI1 transformed cells, both the cell growth capacity in the galactose medium and the resistance to cell death under apoptotic induction and oxidative stress have been increased. These results suggested ROS might mediate the cell death pathway in the LHON patients.

Yeast NDI1 gene has been introduced to more than 10 cell lines [25-27, 60-62], including nonproliferating cells, mouse skeletal muscle, and substantia nigra. The results obtained in the present work further provided strong evidence to support NDI1 as a tool to decrease the oxidative stress in the cells carrying a pathogenic mutation. The utilization of NDI1 in the treatment of neurodegenerative diseases caused by complex I defects including LHON looks promising.

\section{Acknowledgments}

We thank Dr. Anne Chomyn for Le1.3.1 cell line and discussion, Dr Takao Yagi for plasmid pHook(NDI1), Dr. Jian-Hong Deng for performing the cell death assay with induction of Fas-ligand, Stephanie Zimmer and Christopher Flores for reading the manuscript. This work was initiated in 
Giuseppe Attardi's lab at Caltech where YB was a postdoctoral fellow. These investigations were supported by a research grant from NIH(1 R01 AG025223 to YB), and Yidong Bai is an Ellison Medical Foundation New Scholar in Aging (AG-NS-0183-02).

\section{References}

[1] T. Yagi, B.B. Seo, S. Di Bernardo, E. Nakamaru-Ogiso, M.C. Kao and A. Matsuno-Yagi, NADH dehydrogenases: from basic science to biomedicine, J Bioenerg Biomembr 33, (2001) 233-42.

[2] J.E. Walker, The NADH:ubiquinone oxidoreductase (complex I) of respiratory chains, Q Rev Biophys 25, (1992) 253-324.

[3] J. Carroll, R.J. Shannon, I.M. Fearnley, J.E. Walker and J. Hirst, Definition of the nuclear encoded protein composition of bovine heart mitochondrial complex I. Identification two new subunits, J Biol Chem 277, (2002) 50311-7.

[4] A. Chomyn, P. Mariottini, M.W. Cleeter, C.I. Ragan, A. Matsuno-Yagi, Y. Hatefi, R.F. Doolittle and G. Attardi, Six unidentified reading frames of human mitochondrial DNA encode components of the respiratory-chain NADH dehydrogenase, Nature 314, (1985) 592-7.

[5] A. Chomyn, M.W. Cleeter, C.I. Ragan, M. Riley, R.F. Doolittle and G. Attardi, URF6, last unidentified reading frame of human mtDNA, codes for an NADH dehydrogenase subunit, Science 234, (1986) 614-8.

[6] J.L. Loeffen, J.A. Smeitink, J.M. Trijbels, A.J. Janssen, R.H. Triepels, R.C. Sengers and L.P. van den Heuvel, Isolated complex I deficiency in children: clinical, biochemical and genetic aspects, Hum Mutat 15, (2000) 123-34.

[7] A.H. Schapira, Human complex I defects in neurodegenerative diseases, Biochim Biophys Acta 1364, (1998) 261-70.

[8] K. Huoponen, Leber hereditary optic neuropathy: clinical and molecular genetic findings, Neurogenetics 3, (2001) 119-25.

[9] T. Leber, Uber hereditare und congenital-angelegte Sehnervenleiden., Graefe's Archives fur Ophthalmologie 17, (1871) 249-91.

[10] E. Nikoskelainen, New aspects of the genetic, etiologic, and clinical puzzle of Leber's disease, Neurology 34, (1984) 1482-4.

[11] T. Seedorff, The inheritance of Leber's disease. A genealogical follow-up study, Acta Ophthalmol (Copenh) 63, (1985) 135-45.

[12] D.C. Wallace, G. Singh, M.T. Lott, J.A. Hodge, T.G. Schurr, A.M. Lezza, L.J. Elsas, 2nd and E.K. Nikoskelainen, Mitochondrial DNA mutation associated with Leber's hereditary optic neuropathy, Science 242, (1988) 1427-30.

[13] N. Howell, S. Halvorson, I. Kubacka, D.A. McCullough, L.A. Bindoff and D.M. Turnbull, Mitochondrial gene segregation in mammals: is the bottleneck always narrow?, Hum Genet 90, (1992) 117-20. 
[14] K. Huoponen, J. Vilkki, P. Aula, E.K. Nikoskelainen and M.L. Savontaus, A new mtDNA mutation associated with Leber hereditary optic neuroretinopathy, Am J Hum Genet 48, (1991) 1147-53.

[15] D. Mackey and N. Howell, A variant of Leber hereditary optic neuropathy characterized by recovery of vision and by an unusual mitochondrial genetic etiology, Am J Hum Genet 51, (1992) 1218-28.

[16] N. Howell, Leber hereditary optic neuropathy: mitochondrial mutations and degeneration of the optic nerve, Vision Res 37, (1997) 3495-507.

[17] R.M. Chalmers and A.H. Schapira, Clinical, biochemical and molecular genetic features of Leber's hereditary optic neuropathy, Biochim Biophys Acta 1410, (1999) 147-58.

[18] P.Y. Man, D.M. Turnbull and P.F. Chinnery, Leber hereditary optic neuropathy, J Med Genet 39, (2002) 162-9.

[19] N.G. Larsson, O. Andersen, E. Holme, A. Oldfors and J. Wahlstrom, Leber's hereditary optic neuropathy and complex I deficiency in muscle, Ann Neurol 30, (1991) 701-8.

[20] G. Hofhaus, D.R. Johns, O. Hurko, G. Attardi and A. Chomyn, Respiration and growth defects in transmitochondrial cell lines carrying the 11778 mutation associated with Leber's hereditary optic neuropathy, J Biol Chem 271, (1996) 13155-61.

[21] S. De Vries, R. Van Witzenburg, L.A. Grivell and C.A. Marres, Primary structure and import pathway of the rotenone-insensitive NADH-ubiquinone oxidoreductase of mitochondria from Saccharomyces cerevisiae, Eur J Biochem 203, (1992) 587-92.

[22] C.A. Marres, S. de Vries and L.A. Grivell, Isolation and inactivation of the nuclear gene encoding the rotenone-insensitive internal NADH: ubiquinone oxidoreductase of mitochondria from Saccharomyces cerevisiae, Eur J Biochem 195, (1991) 857-62.

[23] S. de Vries and L.A. Grivell, Purification and characterization of a rotenone-insensitive NADH:Q6 oxidoreductase from mitochondria of Saccharomyces cerevisiae, Eur J Biochem 176, (1988) 377-84.

[24] T. Kitajima-Ihara and T. Yagi, Rotenone-insensitive internal NADH-quinone oxidoreductase of Saccharomyces cerevisiae mitochondria: the enzyme expressed in Escherichia coli acts as a member of the respiratory chain in the host cells, FEBS Lett 421, (1998) 37-40.

[25] B.B. Seo, T. Kitajima-Ihara, E.K. Chan, I.E. Scheffler, A. Matsuno-Yagi and T. Yagi, Molecular remedy of complex I defects: rotenone-insensitive internal NADH-quinone oxidoreductase of Saccharomyces cerevisiae mitochondria restores the NADH oxidase activity of complex I-deficient mammalian cells, Proc Natl Acad Sci U S A 95, (1998) 9167-71.

[26] B.B. Seo, A. Matsuno-Yagi and T. Yagi, Modulation of oxidative phosphorylation of human kidney 293 cells by transfection with the internal rotenone-insensitive NADHquinone oxidoreductase (NDI1) gene of Saccharomyces cerevisiae, Biochim Biophys Acta 1412, (1999) 56-65.

[27] Y. Bai, P. Hajek, A. Chomyn, E. Chan, B.B. Seo, A. Matsuno-Yagi, T. Yagi and G. Attardi, Lack of Complex I Activity in Human Cells Carrying a Mutation in MtDNAencoded ND4 Subunit Is Corrected by the Saccharomyces cerevisiae NADH-Quinone Oxidoreductase (NDI1) Gene, J Biol Chem 276, (2001) 38808-13.

[28] C.A. Chen and H. Okayama, Calcium phosphate-mediated gene transfer: a highly efficient transfection system for stably transforming cells with plasmid DNA, Biotechniques 6, (1988) 632-8. 
[29] Y. Bai, R.M. Shakeley and G. Attardi, Tight control of respiration by NADH dehydrogenase ND5 subunit gene expression in mouse mitochondria, Mol Cell Biol 20, (2000) 805-15.

[30] J.H. Deng, Y. Li, J.S. Park, J. Wu, P. Hu, J. Lechleiter and Y. Bai, Nuclear Suppression of Mitochondrial Defects in Cells without the ND6 Subunit, Mol Cell Biol 26, (2006) 1077-86.

[31] X.X. Zheng, J.M. Shoffner, A.S. Voljavec and D.C. Wallace, Evaluation of procedures for assaying oxidative phosphorylation enzyme activities in mitochondrial myopathy muscle biopsies, Biochim Biophys Acta 1019, (1990) 1-10.

[32] M.A. Birch-Machin and D.M. Turnbull, Assaying mitochondrial respiratory complex activity in mitochondria isolated from human cells and tissues, Methods Cell Biol 65, (2001) 97-117.

[33] L.G. Nijtmans, N.S. Henderson and I.J. Holt, Blue Native electrophoresis to study mitochondrial and other protein complexes, Methods 26, (2002) 327-34.

[34] H. Schagger, Electrophoretic techniques for isolation and quantification of oxidative phosphorylation complexes from human tissues, Methods Enzymol 264, (1996) 555-66.

[35] G. Manfredi, A. Spinazzola, N. Checcarelli and A. Naini, Assay of mitochondrial ATP synthesis in animal cells, Methods Cell Biol 65, (2001) 133-45.

[36] M. Degli Esposti and H. McLennan, Mitochondria and cells produce reactive oxygen species in virtual anaerobiosis: relevance to ceramide-induced apoptosis, FEBS Lett 430, (1998) 338-42.

[37] Y. Bai, P. Hu, J.S. Park, J.H. Deng, X. Song, A. Chomyn, T. Yagi and G. Attardi, Genetic and functional analysis of mitochondrial DNA-encoded complex I genes, Ann N Y Acad Sci 1011, (2004) 272-83.

[38] H. Schagger, Native electrophoresis for isolation of mitochondrial oxidative phosphorylation protein complexes, Methods Enzymol 260, (1995) 190-202.

[39] D.S. Albers and M.F. Beal, Mitochondrial dysfunction and oxidative stress in aging and neurodegenerative disease, J Neural Transm Suppl 59, (2000) 133-54.

[40] A. Wong and G. Cortopassi, mtDNA mutations confer cellular sensitivity to oxidant stress that is partially rescued by calcium depletion and cyclosporin A, Biochem Biophys Res Commun 239, (1997) 139-45.

[41] I. Morita, W.L. Smith, D.L. DeWitt and M. Schindler, Expression-activity profiles of cells transfected with prostaglandin endoperoxide $\mathrm{H}$ synthase measured by quantitative fluorescence microscopy, Biochemistry 34, (1995) 7194-9.

[42] N. Howell, Leber hereditary optic neuropathy: how do mitochondrial DNA mutations cause degeneration of the optic nerve?, J Bioenerg Biomembr 29, (1997) 165-73.

[43] M.R. Ciriolo, K. Aquilano, A. De Martino, M.T. Carri and G. Rotilio, Differential role of superoxide and glutathione in S-nitrosoglutathione-mediated apoptosis: a rationale for mild forms of familial amyotrophic lateral sclerosis associated with less active $\mathrm{Cu}, \mathrm{Zn}$ superoxide dismutase mutants, J Neurochem 77, (2001) 1433-43.

[44] A. Baracca, G. Solaini, G. Sgarbi, G. Lenaz, A. Baruzzi, A.H. Schapira, A. Martinuzzi and V. Carelli, Severe impairment of complex I-driven adenosine triphosphate synthesis in leber hereditary optic neuropathy cybrids, Arch Neurol 62, (2005) 730-6.

[45] M.D. Brown, The enigmatic relationship between mitochondrial dysfunction and Leber's hereditary optic neuropathy, J Neurol Sci 165, (1999) 1-5. 
[46] V. Carelli, M. Rugolo, G. Sgarbi, A. Ghelli, C. Zanna, A. Baracca, G. Lenaz, E. Napoli, A. Martinuzzi and G. Solaini, Bioenergetics shapes cellular death pathways in Leber's hereditary optic neuropathy: a model of mitochondrial neurodegeneration, Biochim Biophys Acta 1658, (2004) 172-9.

[47] J. Guy, X. Qi, F. Pallotti, E.A. Schon, G. Manfredi, V. Carelli, A. Martinuzzi, W.W. Hauswirth and A.S. Lewin, Rescue of a mitochondrial deficiency causing Leber Hereditary Optic Neuropathy, Ann Neurol 52, (2002) 534-42.

[48] T. Yagi, Bacterial NADH-quinone oxidoreductases, J Bioenerg Biomembr 23, (1991) 211-25.

[49] R. Acin-Perez, M.P. Bayona-Bafaluy, P. Fernandez-Silva, R. Moreno-Loshuertos, A. Perez-Martos, C. Bruno, C.T. Moraes and J.A. Enriquez, Respiratory complex III is required to maintain complex I in mammalian mitochondria, Mol Cell 13, (2004) 805-15.

[50] H. Schagger, R. de Coo, M.F. Bauer, S. Hofmann, C. Godinot and U. Brandt, Significance of respirasomes for the assembly/stability of human respiratory chain complex I, J Biol Chem 279, (2004) 36349-53.

[51] H. Schagger, Respiratory chain supercomplexes, IUBMB Life 52, (2001) 119-28.

[52] T. Yagi, B.B. Seo, E. Nakamaru-Ogiso, M. Marella, J. Barber-Singh, T. Yamashita and A. Matsuno-Yagi, Possibility of transkingdom gene therapy for Complex I diseases, Biochim Biophys Acta, (2006).

[53] T. Yagi, B.B. Seo, E. Nakamaru-Ogiso, M. Marella, J. Barber-Singh, T. Yamashita, M.C. Kao and A. Matsuno-Yagi, Can a Single Subunit Yeast NADH Dehydrogenase (Ndi1) Remedy Diseases Caused by Respiratory Complex I Defects?, Rejuvenation Res 9, (2006) 191-7.

[54] A. Wong, L. Cavelier, H.E. Collins-Schramm, M.F. Seldin, M. McGrogan, M.L. Savontaus and G.A. Cortopassi, Differentiation-specific effects of LHON mutations introduced into neuronal NT2 cells, Hum Mol Genet 11, (2002) 431-8.

[55] X. Qi, A.S. Lewin, W.W. Hauswirth and J. Guy, Optic neuropathy induced by reductions in mitochondrial superoxide dismutase, Invest Ophthalmol Vis Sci 44, (2003) 1088-96.

[56] S. Beretta, L. Mattavelli, G. Sala, L. Tremolizzo, A.H. Schapira, A. Martinuzzi, V. Carelli and C. Ferrarese, Leber hereditary optic neuropathy mtDNA mutations disrupt glutamate transport in cybrid cell lines, Brain 127, (2004) 2183-92.

[57] A. Ghelli, C. Zanna, A.M. Porcelli, A.H. Schapira, A. Martinuzzi, V. Carelli and M. Rugolo, Leber's hereditary optic neuropathy (LHON) pathogenic mutations induce mitochondrial-dependent apoptotic death in transmitochondrial cells incubated with galactose medium, J Biol Chem 278, (2003) 4145-50.

[58] C. Zanna, A. Ghelli, A.M. Porcelli, A. Martinuzzi, V. Carelli and M. Rugolo, Caspaseindependent death of Leber's hereditary optic neuropathy cybrids is driven by energetic failure and mediated by AIF and Endonuclease G, Apoptosis 10, (2005) 997-1007.

[59] S.R. Danielson, A. Wong, V. Carelli, A. Martinuzzi, A.H. Schapira and G.A. Cortopassi, Cells bearing mutations causing Leber's hereditary optic neuropathy are sensitized to FasInduced apoptosis, J Biol Chem 277, (2002) 5810-5.

[60] B.B. Seo, J. Wang, T.R. Flotte, T. Yagi and A. Matsuno-Yagi, Use of the NADHquinone oxidoreductase (NDI1) gene of Saccharomyces cerevisiae as a possible cure for complex I defects in human cells, J Biol Chem 275, (2000) 37774-8. 
[61] B.B. Seo, E. Nakamaru-Ogiso, T.R. Flotte, T. Yagi and A. Matsuno-Yagi, A singlesubunit NADH-quinone oxidoreductase renders resistance to mammalian nerve cells against complex I inhibition, Mol Ther 6, (2002) 336-41.

[62] T.B. Sherer, R. Betarbet, C.M. Testa, B.B. Seo, J.R. Richardson, J.H. Kim, G.W. Miller, T. Yagi, A. Matsuno-Yagi and J.T. Greenamyre, Mechanism of toxicity in rotenone models of Parkinson's disease, J Neurosci 23, (2003) 10756-64. 


\section{Legends to figures}

Fig. 1. Detection of the NDI1 gene and mRNA in transfectant cells. (A) PCR amplification was carried out with total cell DNA using two sets of primers specific for the human mitochondrial ND4 gene and the yeast NDI1 gene. The products were analyzed by $1 \%$ agarose gel electrophoresis. (B) Total RNA from various cells was subjected to RT-PCR, using the same primers employed in the DNA analysis, and the products were analyzed by $1 \%$ agarose gel electrophoresis.

Fig. 2. Detection of mtDNA G11778A mutation in Le1.3.1 and LeNDI1-1, -2cells. The G to A transition at position 11778 creates a MaeIII restriction site. The 896bp portion of wildtype ND4 gene amplified by PCR (A) contains three MaeIII sites and will yield bands at 346, 255 and 238bp after digestion (B). With the mutant mtDNA, the $255 \mathrm{bp}$ fragment will be further cut into two smaller bands at 131 and $124 \mathrm{bp}$. The MaeIII digestion products were separated by electrophoresis on an $8 \%$ polyacrylamide gel.

Fig. 3. Respiration measurements in 143B, Le1.3.1, and LeNDI1-1, -2 cells., (A) Endogenous respiration measured in intact cells and after treatment with uncoupler FCCP. (B) The complex dependent activities of respiration in permeabilized cells driven by glutamate/malate (G/M), glycerol-3phosphate/succinate (G-3-P/S), and ascorbate/TMPD (A/TMPD). (C) The resistance to respiration inhibitors rotenone and flavone to complex I-dependent respiration, antimycin A to complex IIIdependent respiration, in permeabilized cells.

Fig. 4. Respiratory complexes assembly analysis. Mitochondria were extracted and protein complexes were separated on a 4-13\% blue native polyacrylamide gel. Complex I, II, III, IV and V were identified 
by western blot with antibody against NDUFA9, SDHA, complex III-core 2, complex IV-subunit I and complex V- $\alpha$ subunit respectively.

Fig.5. ATP content analysis. The total cellular ATP contents in 143B, Le1.3.1, and LeNDI1-1, -2 cells were measured in $1 \times 10^{6}$ cells with a luciferase detection kit. The oligomycin resistant ATP contents (Oligomycin-R) were determined after cells were incubated with oligomycin, an inhibitor of oxidative phosphorylation, for $1 \mathrm{hr}$ at $37^{\circ} \mathrm{C}$ at the concentration of $15 \mu \mathrm{g} / \mathrm{ml}$. The oligomycin-sensitive ATP production (Oligomycin-S) was calculated by subtracting of oligomycin sensitive portion from the total ATP content. Four measurements were carried out, and the error bars indicate 2 times of the standard errors of the mean.

Fig. 6. Growth capacity of 143B, Le1.3.1, and LeNDI1-1, -2 cells in glucose and galactose-containing DMEM. Cells were plated on multiple 6 well plates at 5 x $10^{3}$ per well and counted on a daily basis for 7 days in glucose (A) and galactose (B) media.

Fig. 7. Measurement of ROS in 143B, Le1.3.1, and LeNDI1-1,- 2 cells. ROS were measured with two different methods. (A) Cells were harvested and suspended in a loading medium contained with $1 \mu \mathrm{M}$ carboxy- $\mathrm{H}_{2}$-DCFDA. (B) Cells were labeled with 100nM Mitosox Red reagent. Values shown are the mean \pm SEM of 3 independent experiments.

Fig.8._Apoptosis assay. Percent of apoptotic cell numbers of 143B, Le1.3.1, and LeNDI1-1, -2 cells incubated for 6 hours with 500nM staurosporine (A), or 48 hours with $250 \mu \mathrm{M}$ Paraquat (B). The apoptotic cells were defined by round and/or shrunken nuclei of DAPI-stained cells. . Percent of TUNEL positive cells of 143B, Le1.3.1, and LeNDI1-1, -2 cells treated with 500nM Staurosphorine (C) and $250 \mathrm{mM}$ of Paraquat (D) were analyzed by visualizing labeled nick ends of DNA strands with the TUNEL 
assay kit from Promega. Activities of caspase 3/7 were measured with Caspase-Glo 3/7 kit (Promega) after treatment with $500 \mathrm{nM}$ staurosporine (E) and $250 \mu \mathrm{M}$ paraquat (F) Three independent measurements for each assay were carried out, and the error bars indicate 2 times of the standard errors of the mean. 
Table 1. Enzymatic assay.

\begin{tabular}{|c|c|c|c|c|c|c|}
\hline & \multirow{2}{*}{$\begin{array}{c}\text { Control } \\
143 \mathrm{~B}\end{array}$} & \multicolumn{5}{|c|}{ LHON } \\
\hline & & Le1.3.1 & LeNDI1-1 & LeNDI1-2 & LeVec-1 & LeVec-2 \\
\hline Complex I & $0.11 \pm 0.0116$ & $0.03 \pm 0.0047^{* *}$ & $0.12 \pm 0.0116^{* * *}$ & $67^{* *}$ & $0.02 \pm 0.0028$ & $0.05 \pm 0.0206$ \\
\hline Complex III & $0.36 \pm 0.0096$ & $0.34 \pm 0.0063$ & $0.29 \pm 0.0080^{*}$ & $0.29 \pm 0.0071^{*}$ & $0.31 \pm 0.0035$ & $0.44 \pm 0.0364$ \\
\hline Complex IV & $0.11 \pm 0.0165$ & $0.11 \pm 0.0120$ & $0.13 \pm 0.0285$ & $0.10 \pm 0.0137$ & $0.21 \pm 0.0152$ & $0.12 \pm 0.0207$ \\
\hline
\end{tabular}

Enzyme activities are expressed in $\mathrm{nmol} \cdot \min ^{-1} \cdot(\mathrm{mg} \text { protein })^{-1}$. Values shown are the mean \pm SEM of 3 independent experiments.

Statistical significance: $*(p<0.05), * *(p<0.01)$, and $* * *(\mathrm{p}<0.005)$ by the ANOVA-test. 
TIY. I

A

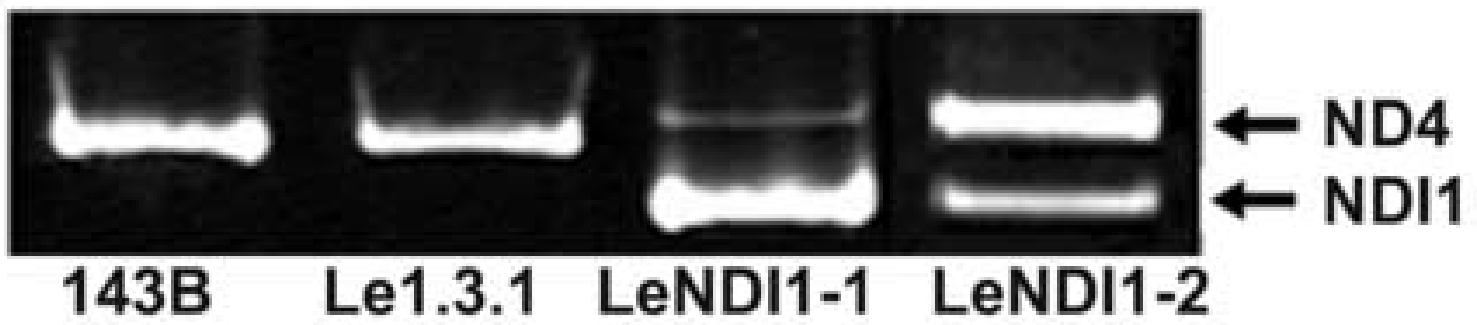

B

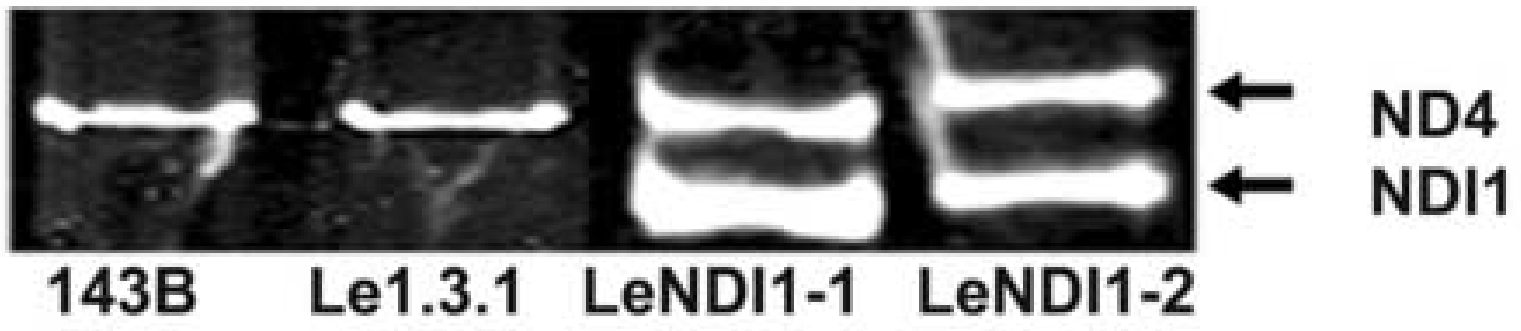


Fig 2

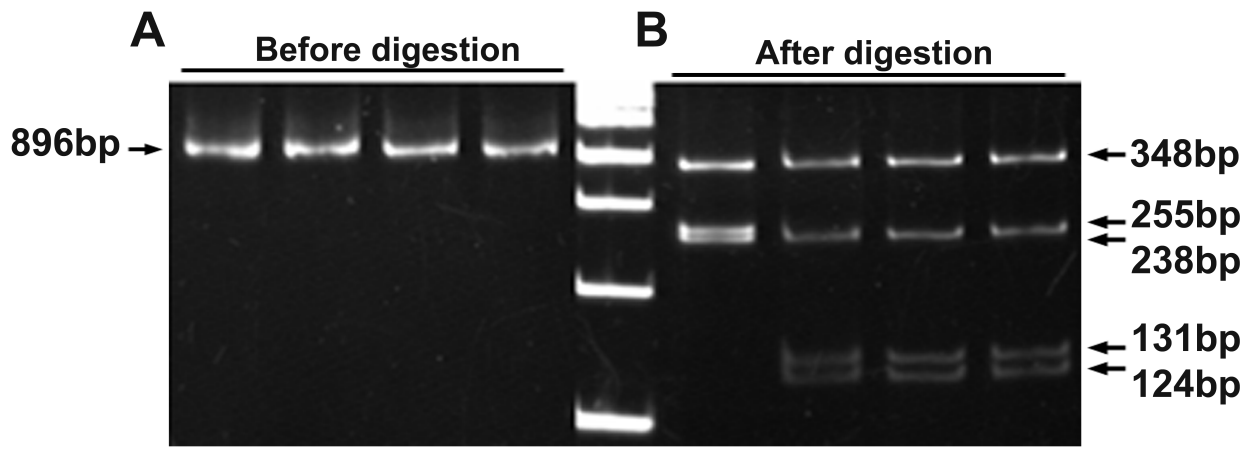


Fig3

A

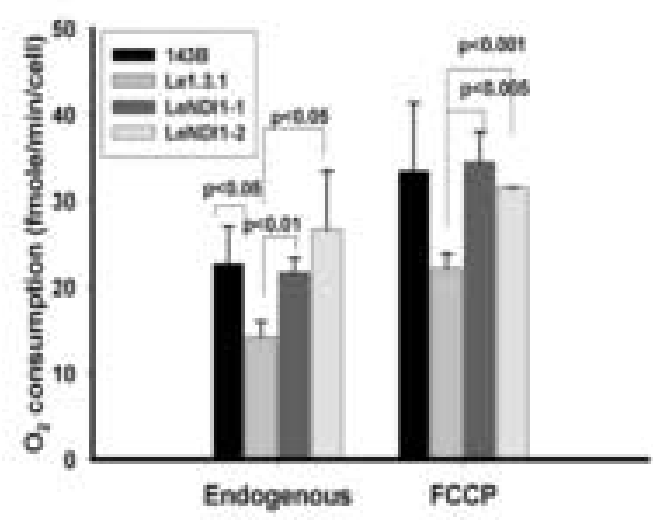

B

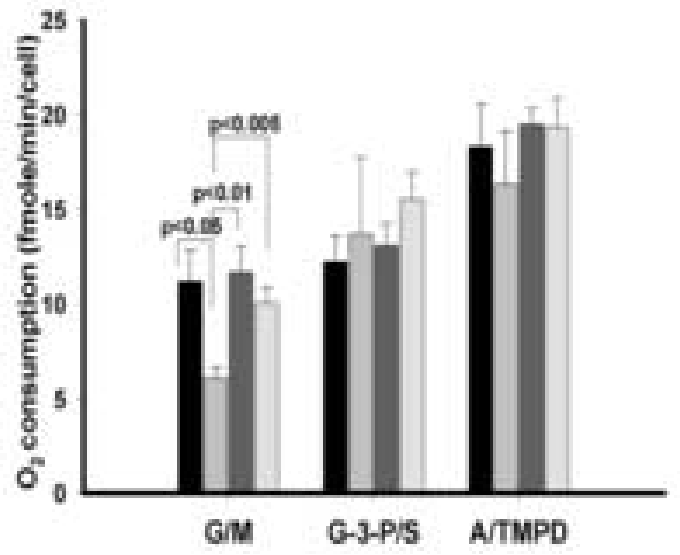

C

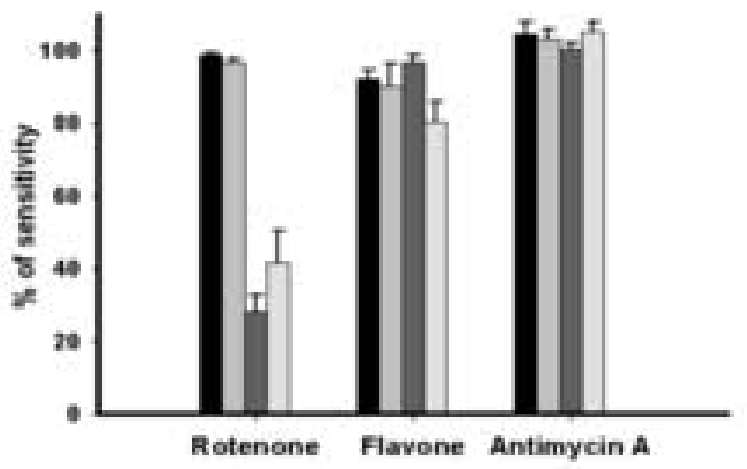


Complex

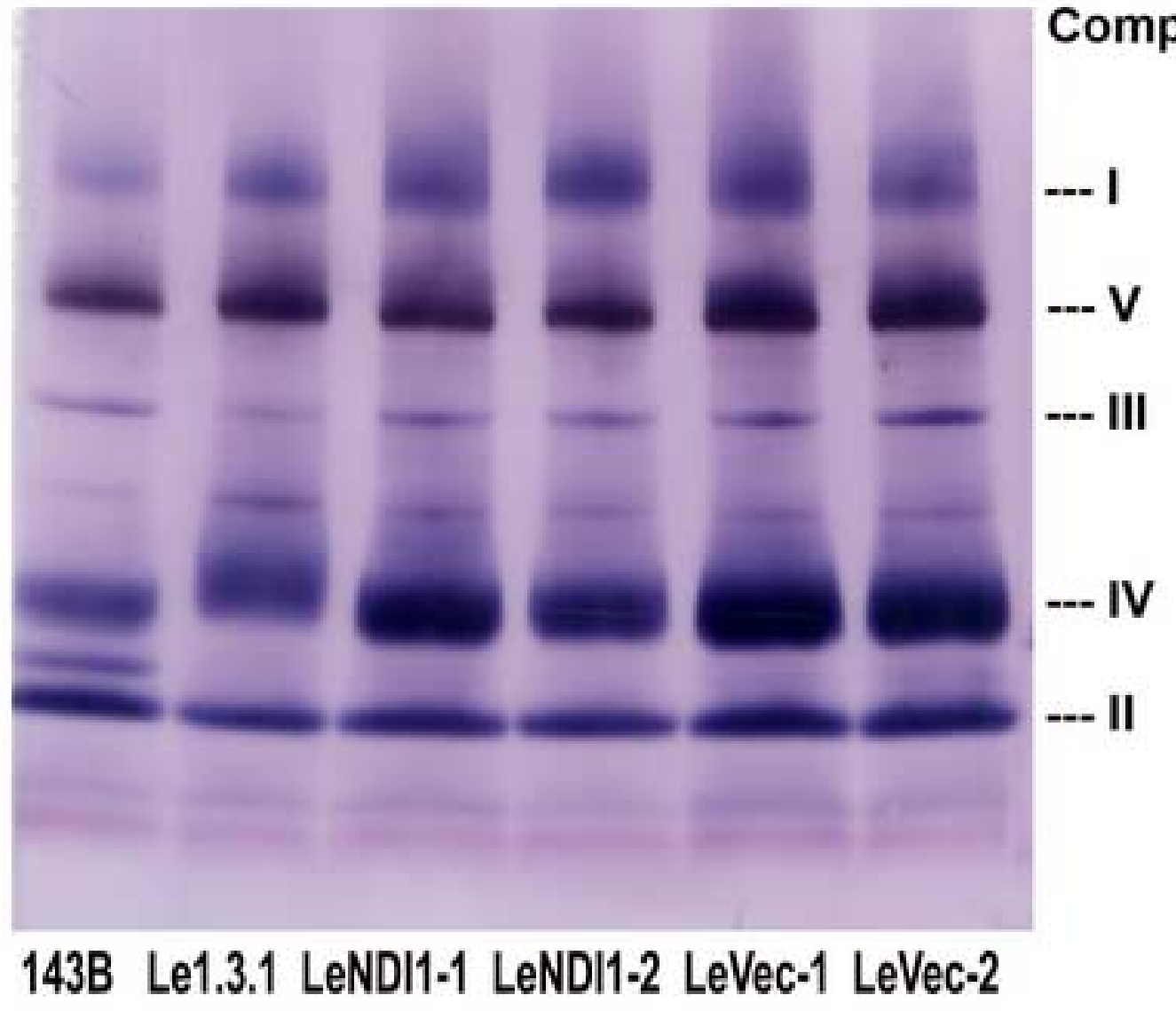


Fig. 5

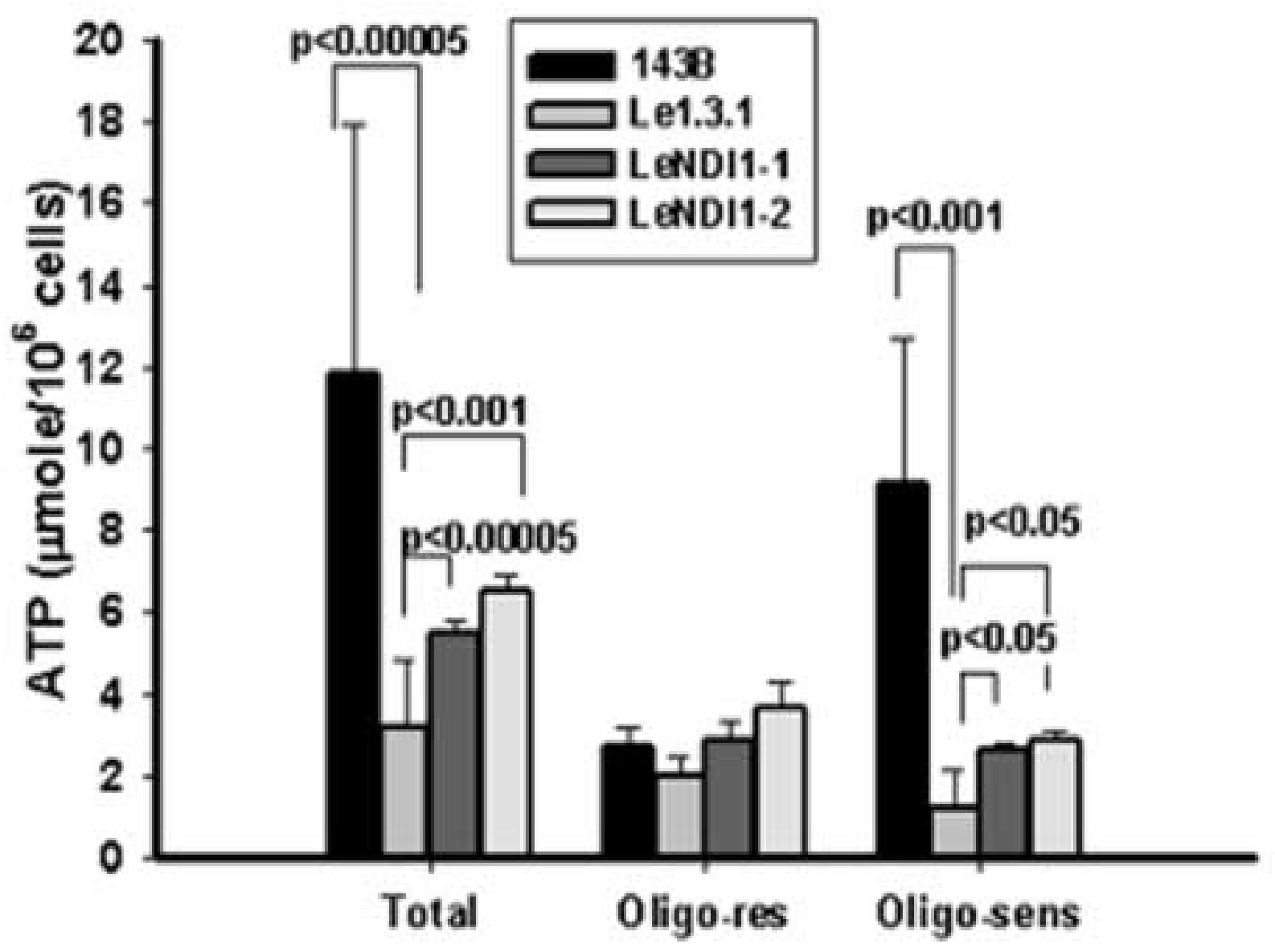




\section{Glucose medium}

Fig 6

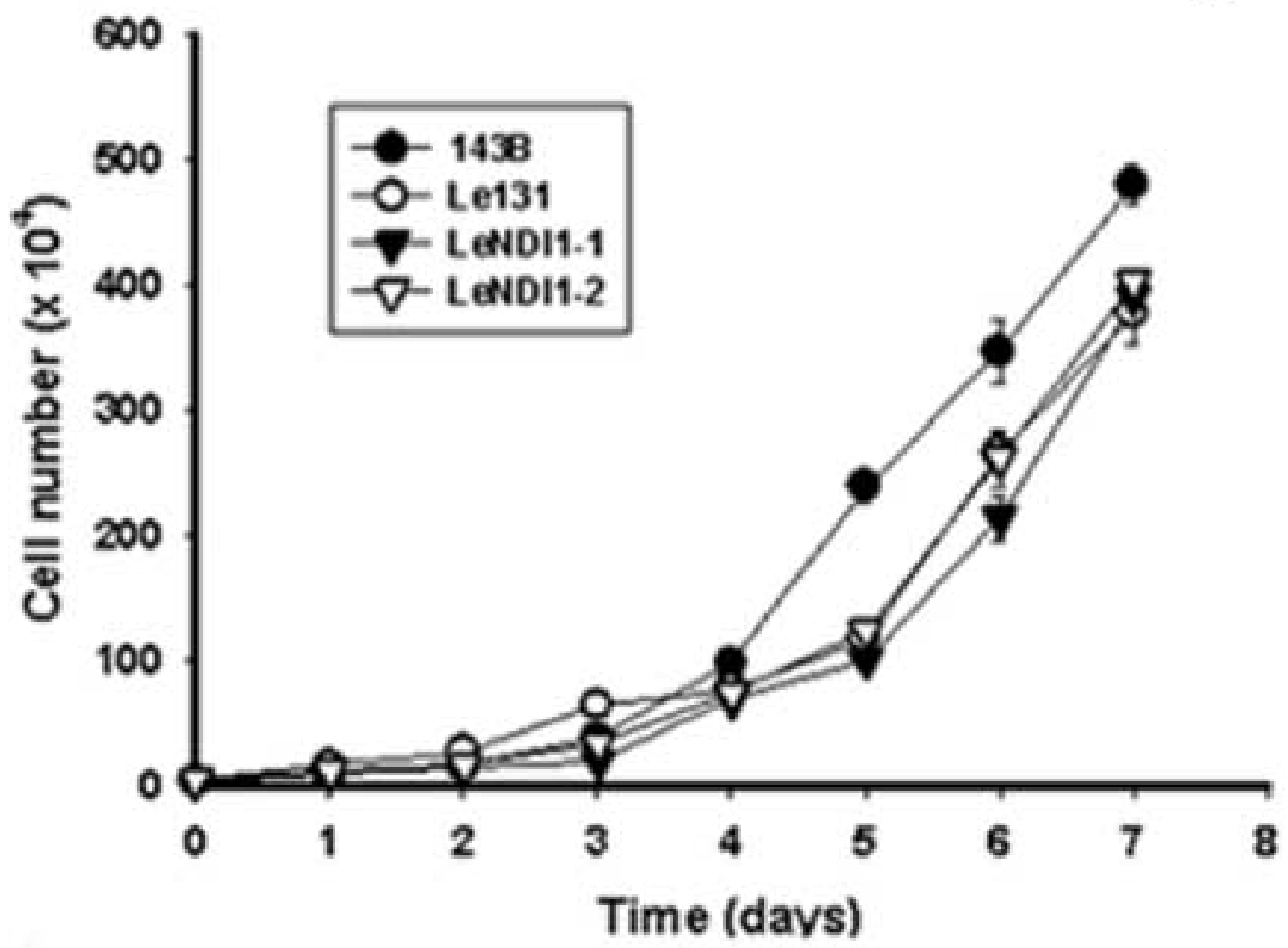

Galactose medium

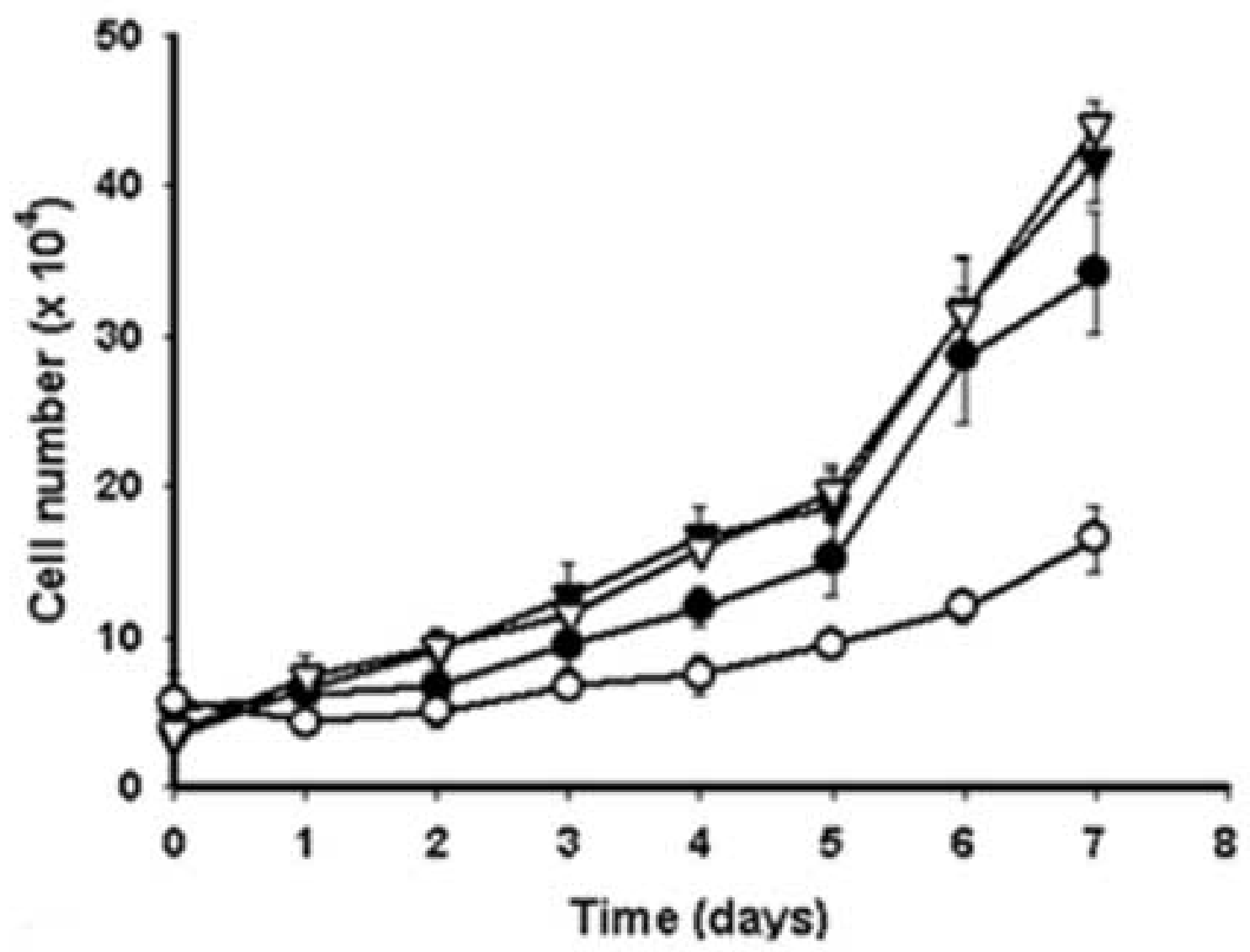


Fig.7

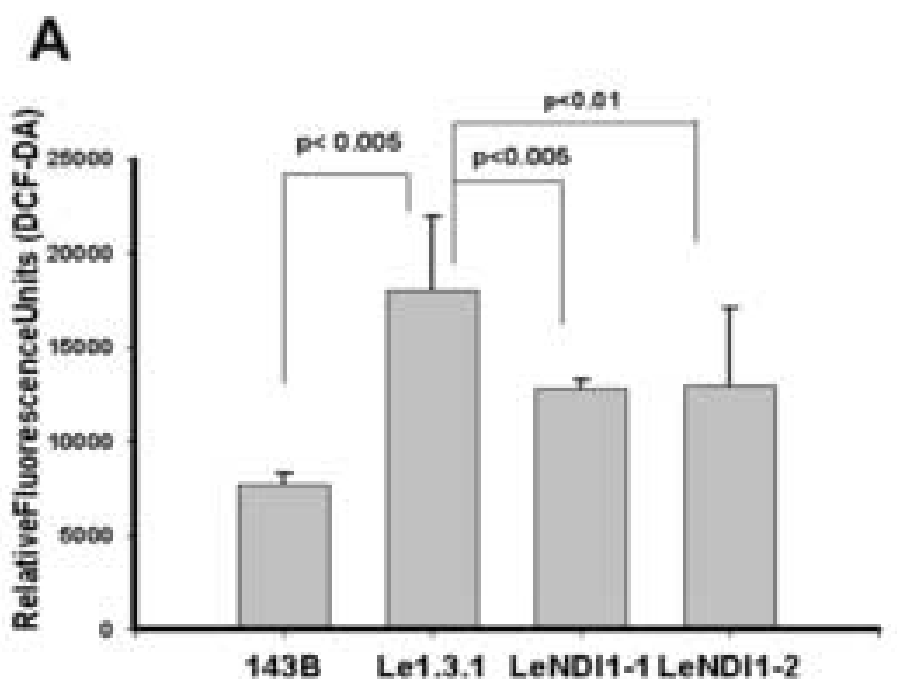

B

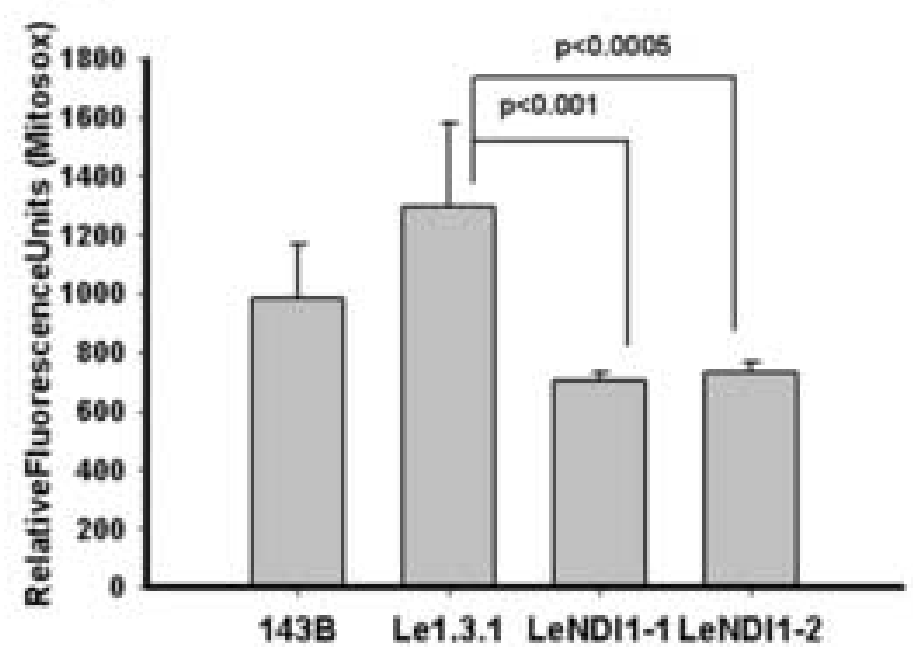




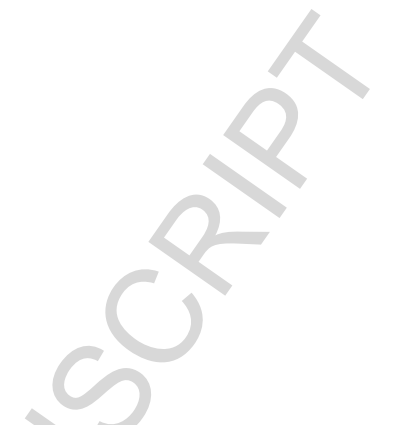

A

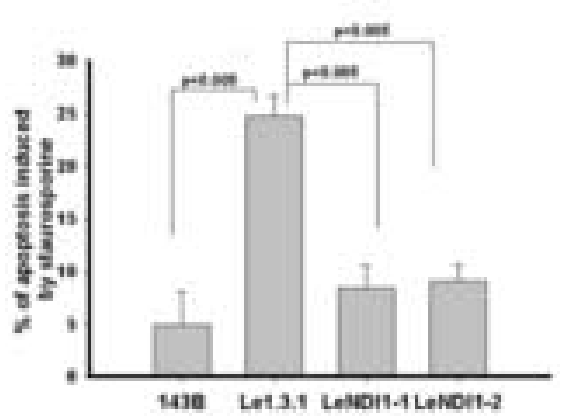

C

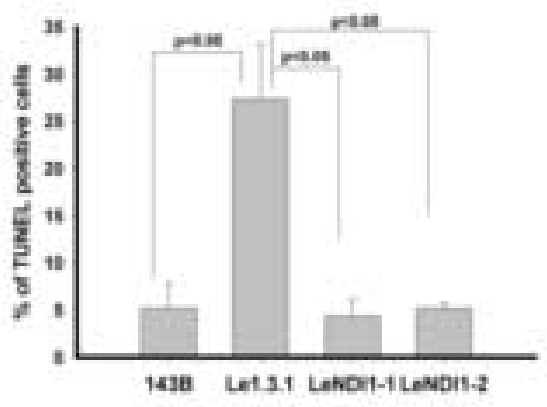

E

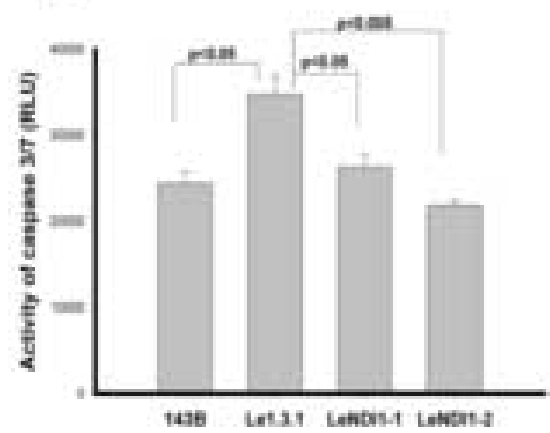

B

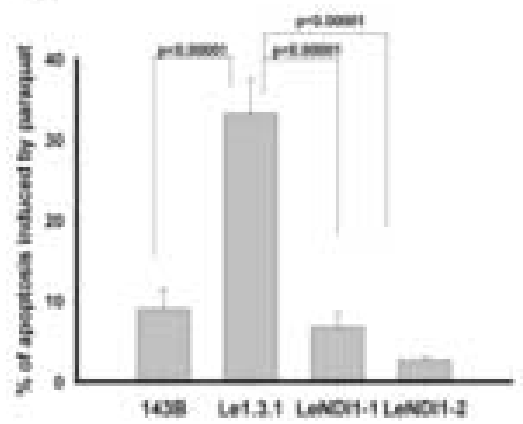

D

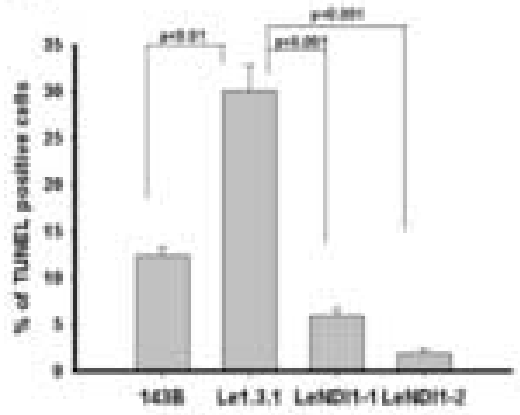

F

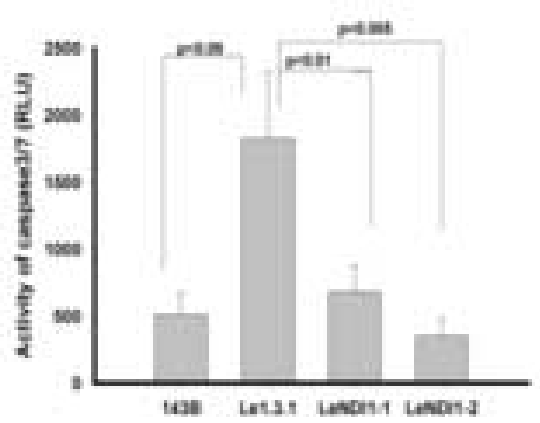

